\title{
Peningkatan Keterampilan Partisipasi Siswa Melalui Metode Think Pair Share Di Sekolah Dasar
}

\author{
Tesy Widya Heriyany ${ }^{1}$, Sumianto ${ }^{2}$, Yanti Yandri Kusuma ${ }^{3}$ \\ Program Studi Pendidikan Guru Sekolah Dasar, FIP, Universitas Pahlawan Tuanku Tambusai \\ E-mail: tessyheriany1@gmail.com
}

\begin{abstract}
Abstrak
Penelitian ini bertujuan untuk mengetahui peningkatkan keterampilan partisipasi siswa melalui metode think pair share pada pembelajaran PKn kelas IV SDN 023 Muara Mahat Baru kecamatan tapung kabupaten Kampar. Metode penelitian ini adalah penelitian Tindakan Kelas (PTK) yang dilaksanakan dalam dua siklus, setiap siklus terdiri dari dua kali pertemuan dan empat tahap, yaitu perencanaan, tindakan, pengamatan, evaluasi, dan waktu penelitian dilaksanakan penelitian ini dikarnakan sekolah ini mengalami rendahnya tingkat partisipasi siswa dalam belajar. Subjek penelitian ini siswa kelas IV SDN 023 Muara Mahat Baru yang berjumlah 27 orang, dengan jumlah laki-laki 15 orang dan jumlah siswa perempuan 12 orang. Teknik pengumpulan data dalam penelitian ini menggunakan teknik obsevasi dan lembar dokumentasi. Hasil penelitian ini dapat disimpulkan bahwa keterampilan partisipasi siswa dengan tema Indahnya kebersamaan kelas IV SDN 023 Muara Mahat Baru,pada pra tindakan tergolong kriteria kurang dengan ketuntasan klasikal $37 \%$ dari 27 orang siswa hanya 10 orang siswa yang tuntas. Pada siklus I dengan kriteria cukup dengan ketuntasan klasikal $48,14 \%$ dari 27 orang siswa hanya 14 orang siswa yang tuntas. Pada siklus II tergolong kriteria baik dengan ketuntasan klasikal 70,37\% dari 27 orang siswa terdapat hanya 19 orang yang tuntas. Dengan demikian dapat disimpulkan bahwa dengan menggunakan metode Think Pair Share dapat peningkatan keterampilan partisipasi siswa kelas IV SDN 023 Muara Mahat Baru.
\end{abstract}

Kata kunci: Keterampilan Partisipasi, Metode Think Pair Share

\section{Abstract}

This study aims to determine the improvement of student participation skills through the method of think pair share in class IV Civics learning at SDN 023 Muara Mahat Baru, Tapung sub-district, Kampar district. The method of this research is Classroom Action Research (CAR) which is carried out in two cycles, each cycle consisting of two meetings and four stages, namely planning, action, observation, evaluation, and the time the research was conducted because this school experienced a low level of student participation in study. The subjects of this research are the fourth grade students of SDN 023 Muara Mahat Baru, which numbered 27 people, with 15 men and 12 female students. Data collection techniques in this study used observation techniques and documentation sheets. The results of this study can be concluded that the skills of student participation with the theme Beautifulness of class IV SDN 023 Muara Mahat Baru, in the preaction classified as less criteria with classical completeness $37 \%$ of 27 students only 10 students who completed. In the first cycle with sufficient criteria with classical completeness $48.14 \%$ of 27 students only 14 students who completed. In the second cycle classified as good criteria with classical completeness $70.37 \%$ of the 27 students there were only 19 people who completed. Thus it can be concluded that using the Think Pair Share method can increase the participation skills of fourth grade students of SDN 023 Muara Mahat Baru.

Keywords: Participation Skills, Think Pair Share Method

\section{PENDAHULUAN}

Setiap Warga Negara Indonesia (WNI) memiliki hak untuk menerima pendidikan yang layak. Pendidikan digunakan sebagai salah satu sarana meningkatkan kualitas sumber daya manusia. Dalam UU No. 20 Tahun 2003 tentang Sistem Pendidikan Nasional dinyatakan bahwa pendidikan 
adalah usaha sadar dan terencana untuk mewujudkan suasana belajar dan proses pembelajaran agar siswa secara aktif mengembangkan potensi dirinya untuk memiliki kekuatan spritual keagamaan, pengendalian diri, kepribadian, kecerdasan, akhlak mulia, serta keterampilan yang diperlukan dirinya, masyarakat, bangsa dan negara.

Crow dan Crow (Rohman, 2009:6) mengemukakan bahwa pendidikan merupakan proses yang berisi berbagai macam kegiatan sesuai individu untuk kehidupan sosialnya dan membantu meneruskan adat dan budaya serta kelembagaan sosial dari generasi ke generasi. Pendidikan terlakasana sepanjang hayat dan pendidikan memiliki kemampuan untuk seiring dengan berkembangnya zaman. Proses dalam penyampaian cara pendidikan yang telah ada adalah salah satu cara yang diaplikasikan secara turun menurun dan menjadi hal pokok yang dilaksanakan. Pelaksanaan pendidikan dalam hal ini dapat disesuaikan dengan kebutuhan masyarakat yang luas yang ada saat ini, mendidik masyarakat lebih diarahkan untuk mendidik sesuai dengan kehidupan dan zaman yang telah dilalui masyarakat pada saat ini.

Proses pembelajaran yang ideal dilaksanakan dalam pembelajaran di kelas adalah kegiatan pembelajaran yang aktif dan adanya proses timbal balik yang akan terjadi antara guru dan siswa, pelaksanaan pembelajaran didalammya akan menumbuhkan strategi yang harus direncanakan oleh guru untuk menyampaikan kepada siswa. Terdapat 5 komponen strategi dalam pembelajaran yaitu 1) Kegiatan pembelajaran, 2) penyampaian informasi, 3) Partispasi siswa, 4) Tes, 5) Kegiatan lanjutan, Solihatin (2012: 3) komponen tersebut terlaksanakan dengan terstruktur disaat pembelajaran berlangsung, dan pembelajaran tidak akan ideal kalau komponen tersebut tidak terlasanakan salah satu.

Pembelajaran yang ideal dalam Partisipasi siswa sangat penting untuk menciptakan pembelajaran yang aktif, kreatif dan menyenangkan dalam proses pembelajaran, sehingga siswa merasa nyaman dalam belajar yang sedang berlangsung. Namun dengan partisipasi ini baik untuk menyusun program untuk melancarkan sehingga proses pembelajaran berjalan dengan baik.Menurut pendapat Sukidin (2002: 158) yang terdapat dalam keterampilan partisipasi yaitu dengan mengajukan pertanyaan, sebaiknya siswa dalam mengajukan pertanyaan siswa seharusnya dengan sopan dan tidak memotong pembicaran guru sedang pembelajaran berlangsung sehingga siswa dalam mengejukan pertanyaan siswa harus menggunakan bahasa yang sopan dan baik. Namun dalam merespon yaitu termasuk dalam menyampaikan usul terhadap apa yang telah disampaikan oleh guru dalam proses pembelajaran saat itu. lalu dalam memberikan sanggahan siswa harus menggunakan bahasa yang sopan dalam memberikan sanggahan sehingga proses pembelajaran berjalan dengan lancar.

Namun kenyataannya berdasarkan hasil observasi yang dilakukan pada tanggal 10 juni 2019 pada kelas IV Sekolah Dasar Negri 023 Muara Mahat Baru, menunjukkan bahwa keterampilan partisipasi siswa masih tergolong rendah . Diketehui bahwa dari 27 orang siswa, 38\% orang siswa yang tuntas atau $62 \%$ siswa yang masih tergolong rendah. Untuk itu lebih jelas bisa dilihat pada tabel dibawah ini:

Tabel 1

Rekapitulasi ketercapaian siswa kelas IV SD Negri 023 Muara Mahat Baru

\begin{tabular}{|c|l|c|c|}
\hline No & \multicolumn{1}{|c|}{ Indikator } & Persentase & Keterangan \\
\hline 1 & Mengajukan pertanyaan & 70,23 & Cukup \\
\hline 2 & Merespon & 24,99 & Sangat kurang \\
\hline 3 & Memberikan sanggahan & 20,74 & Sangat kurang \\
\hline 4 & $\begin{array}{l}\text { Mengikuti pembelajaran } \\
\text { dengan baik tugas }\end{array}$ & 19,98 & Sangat kurang \\
\hline 5 & $\begin{array}{l}\text { Mengerjakan } \\
\text { terstruktur dengan baik }\end{array}$ & Sangat kurang \\
\hline
\end{tabular}

Berdasarkan tabel 1 dapat diketahui bahwa keterampilan partisipsi masih rendah terkait dengan indikator yang masih di kategorikan dengan nilai SB,B,C,K,SK, maka untuk itu dalam indikator mengajukan pertanyaan yang di kategorikan cukup. Selain rendahnya partisipasi siswa dalam belajar masih belum terlihat hal ini menunjukkan rendahnya respon siswa terhadap pembelajaran yang berlangsung, siswa tidak memberikan jawaban atas pertanyaan -pertanyaan yang diberikan sampai guru memindahkan pertanyaan tersebut kebeberapa siswa lainnya, namun siswa diberikan waktu 10 menit dalam menjawab pertanyaan, namun tidak ada satu pun yang bida menjawab pertanyaan-pertanyaan tersebut. Untuk melakukan pembelajaran yang aktif guru harus menciptakan pembelajaran yang lebih menarik, karena dengan guru membuat secara berkelompok dapat meningkatkan siswa dalam keterampilan partisipasi. Namun akibat 
yang timbul apabila keterampilan partisipasi siswa tidak dilakukan karena kurang keaktifan siswa dalam belajar, kurangnya siswa untuk merespon dan berkreasi dalam kegiatan pembelajaran yang dilaksanakan oleh guru, dan kurangnya sifat keterbukaan dan berpendapat antara guru dengan siswa.

\section{METODE PENELITIAN}

Metode penelitian ini adalah Penelitian Tindakan Kelas (PTK). Menurut Tampubolon (2014: 18) Penelitian Tindakan Kelas adalah penelitian yang dilakukan oleh pendidik di dalam kelasnya sendiri melalui refleksi diri. Tujuannya adalah untuk memperbaiki kinerjanya sebagai pendidik, sehingga hasil belajar peserta didik menjadi meningkat dan, secara sistem, mutu pendidikan pada satuan pendidikan juga meningkat. Menurut Arikunto (2014: 3) Penelitian Tindakan Kelas adalah suatu pencermatan terhadap kegiatan belajar berupa sebuah tindakan, yang sengaja dimunculkan dan terjadi dalam sebuah kelas secara bersama. Tindakan tersebut diberikan oleh guru atau dengan arahan dari guru yang dilakukan oleh siswa. Penelitian ini akan dilakukan di kelas IV Sekolah Dasar Negri 023 Muara Mahat Baru, dipilihnya Sekolah Dasar Negri 023 Muara Mahat Baru ini karena lokasi, sebelunya berada di dekat jalan raya, sehingga dapat mempermudah aktivitas atau menempuh sekolah serta fasilitas sekolah tersebut yang telah lengkap. Selama itu dipilihnya sekolah ini peneliti juga menemukan permasalahan rendahnya keterampilan partisipasi siswa dalam belajar terutama dalam pembelajaran PKn. Penelitian ini akan dilaksanakan pada Tahun ajaran 2019/2020 pada bulan Oktober - November, terdiri dari dua siklus, tiap siklus terdiri dari dua kali pertemuan

\section{HASIL PENELITIAN DAN PEMBAHASAN}

Berdasarkan observasi awal yang dilaksanakan di Sekolah Dasar Negeri 023 Muara Mahat Baru pada pembelajaran PKn, guru menjadi penentu utama berjalannya proses belajar mengajar. Guru belum mengoptimalkan keterampilan berpartisipasi sehingga sebagian besar siswa memiliki keterampilan berpartisipasi dalam belajar rendah yang ditunjukkan dengan rendahnya partisipasi siswa dalam pembelajaran PKn. Hasil pratindakan digunakan sebagai perbandingan keterampilan berpartisipasi sebelum dan sesudah menggunakan metode Think Pair Share pada kelas IV Sekolah Dasar Negeri 023 Muara Mahat Baru. Keterampilan partisipasi siswa yang rendah perlu ditingkatkan dengan melakukan tindakan oleh peneliti dan berkolaborasi dengan observer aktivitas guru dan siswa dengan minindak lanjuti melalui kegiatan pembelajaran tematik dengan menggunakan metode pembelajaran Kooperatif Tipe Think Pair Share yang diyakini dapat meningkatkan keterampilan partisipasi siswa. Sebelum pelaksanaan tindakan, peneliti melakukan observasi kembali di kelas IV Sekolah Dasar Negeri 023 Muara Mahat Baru. Berdasarkan hasil observasi, kegiatan yang sudah dilakukan oleh guru adalah kegiatan ceramah, tanya jawab dan sesekali menggunakan metode bercerita. Ketika pembelajaran didalam kelas, siswa cenderung banyak mendengarkan dibandingkan dengan menyampaikan pendapat dengan inisiatif siswa. Keadaan kelas yang cukup heterogen menyebabkan kondisi siswa, terdapat beberapa siswa yang memang sudah cukup berpartisipasi secara aktif, dan ada juga siswa yang sama sekali tidak tertarik ketika pelaksanaan pembelajaran Pkn berlangsung. Siswa yang tidak tertarik, menarik diri dengan meletakkan kepala diatas meja dan bercerita sendiri dengan teman satu bangkunya. Selain itu sesekali siswa bermain buku-buku yang berserakan diatas mejanya diketahui bahwa persentase ketuntasan siswa pada pra tindakan hanya mencapai persentase $37 \%$ atau 10 orang siswa yang tuntas. Persentase tidak tuntas sebesar $63 \%$ atau 17 orang siswa yang tidak tuntas. Kemudian rata-rata skor dasar siswa hanya $57 \%$. dapat diketahui bahwa ketercapaian hasil observasi tingkat partisipasi belajar siswa kelas IV Sekolah Dasar Negeri 023 muara mahat baru masih perlu untuk ditingkatkan. Hal ini dikarenakan dari data tersebut, setengah jumlah dari keseluruhan total siswa belum mencapai kriteria baik dengan presntase $57 \%$ dari jumlah total siswa.

Perbandingan pertisipasi siswa dari pratindakan, siklus I, dan siklus II pada materi pentingnya bekerja sama dengan menggunakan metode Think Pair Share. Untuk mengetahui perkembangan hasil belajar siswa dari sebelum tindakan, siklus I dan siklus II dengan menggunakan metode Think Pair Share pada siswa kelas IV Sekolah Dasar Negeri 023 Muara Mahat Baru secara jelas dapat dilihat pada tabel berikut ini: 
Tabel 2

Rekapitulasi Ketuntasan Indikator Keterampilan

Partisipasi Siswa Pada Siklus I dan siklus II

\begin{tabular}{|c|c|c|c|c|c|c|c|c|c|}
\hline \multirow{2}{*}{ Skor } & \multirow{4}{*}{ Kategori } & \multicolumn{4}{|c|}{ SIKLUS I } & \multicolumn{4}{c|}{ SIKLUS II } \\
\cline { 3 - 10 } & \multicolumn{2}{|c|}{ P1 } & \multicolumn{2}{|c|}{ P2 } & \multicolumn{2}{|c|}{ P1 } & \multicolumn{2}{|c|}{ P2 } \\
\cline { 3 - 10 } & T & TT & T & TT & T & TT & T & TT \\
\hline 90-100\% & $\begin{array}{c}\text { Sangat } \\
\text { baik }\end{array}$ & - & - & 1 & - & 1 & - & 3 & - \\
\hline $80-79 \%$ & Baik & 2 & - & 4 & - & 6 & - & 6 & - \\
\hline $70-79 \%$ & Cukup & 7 & - & 8 & - & 10 & - & 10 & - \\
\hline $60-69 \%$ & Kurang & - & 8 & - & 6 & - & 8 & - & 7 \\
\hline$<60 \%$ & $\begin{array}{c}\text { Sangat } \\
\text { Kurang }\end{array}$ & 10 & & 8 & & 2 & & 1 \\
\hline \multicolumn{2}{|c|}{ Jumlah } & 9 & 18 & 13 & 14 & 17 & 10 & 19 & 8 \\
\hline \multicolumn{2}{|c|}{ Persentase (\%) } & $\begin{array}{c}33.33 \\
\%\end{array}$ & $\begin{array}{c}66,67 \\
\%\end{array}$ & $\begin{array}{c}48,14 \\
\%\end{array}$ & $\begin{array}{c}51,85 \\
\%\end{array}$ & $\begin{array}{c}62,96 \\
\%\end{array}$ & $\begin{array}{c}37,03 \\
\%\end{array}$ & $\begin{array}{c}70,37 \\
\%\end{array}$ & $\begin{array}{c}29,62 \\
\%\end{array}$ \\
\hline
\end{tabular}

Dilihat dari tabel 2 terdapatnya peningkatan pada keterampilan partisipasi siswa melalui metode Think Pair share pada kelas IV SD Negri 023 Muara Mahat Baru. Diketahui bahwa nilai rata-rata siswa pada siklus I pertemuan 1 sebesar 33.33\% dan meningkat pada pertemuan 2 sebesar $48,14 \%$ dengan. Kemudian pada siklus II pertemuan 1 mengalami peningkatan menjadi 62,96\%. Lalu meningkat lagi pada pertemuan 2 menjadi 70,37\%.

Pada siklus II pertemuan 1 meningkat menjadi 62,96\%. Kemudian meningkat lagi pada pertemuan 2 sebesar 70,37\%. Untuk mengetahui perkembangan kemampuan peserta didik dari sebelum tindakan, siklus I dan II pada peserta didik kelas IV Sekolah Dasar Negeri 023 Muara Mahat Baru secara jelas dapat dilihat tabel berikut ini:

Tabel 3

Peningkatan Keterampilan Partisipasi Secara Klasikal Pratindakan, Siklus I, Dan Siklus II

\begin{tabular}{|c|c|c|c|c|c|}
\hline \multirow{2}{*}{$\begin{array}{c}\text { Ketera } \\
\text { ngan }\end{array}$} & \multirow{2}{*}{\begin{tabular}{c} 
D \\
ata \\
\cline { 3 - 6 }
\end{tabular}} & $\begin{array}{c}\text { Pwal } \\
\text { Awrte }\end{array}$ & $\begin{array}{c}\text { Perte } \\
\text { muan I }\end{array}$ & $\begin{array}{c}\text { Perte } \\
\text { muan II } \\
\text { muan I }\end{array}$ & $\begin{array}{c}\text { Perte } \\
\text { muan II }\end{array}$ \\
\hline tase Kalsikal & $7 \%$ & 33,33 & 48,14 & 62,96 & $70,37 \%$ \\
$\%$ & $\%$ & & \\
\hline
\end{tabular}

(Sumber: Data hasil obs1ervasi keterampilan psrtisipasi siswa)

Berdasarkan table 3 menunjukkan bahwa persentase keterampilan berbicara peserta didik mengalami peningkatan per pertemuan dan persiklus persentase data awal peserta didik (15.83)\% meningkat pada siklus 1 pertemuan $1(33,33) \%$ kemudian meningkat pada pertemuan 2 siklus $1(48,14) \%$ kemudian meningkat pada siklus 2 pertemuan $1(62,96) \%$ kemudian meningkat pada pertemuan 2 siklus $2(70,37) \%$.

Berdasarkan uraian hasil keterampialn partisipasi siswa maka penelitian menguraikan beberapa hal yang perlu di bahas terkait penelitian ini yaitu: Pada perencanaan siklus I dan siklus II dalam keterampilan partisipasi siswa kelas IV Sekolah Dasar Negeri 023 Muara Mahat Baru. Peneliti harus menyiapkan perencanaan pembelajaran karena proses pembelajaran perlu direncanakan, adapun perencanaan yang dilakukan oleh peneliti dalam penelitian ini yaitu : menyusun instrumen penelitian berupa silabus, menyusun RPP, menyiapkan lembar observasi aktivitas guru dan kemudian lembar aktivitas belajar siswa, meminta teman untuk observer aktivitas guru, dan meminta teman sejawat untuk menjadi observer aktivitas siswa. Adapun komponen-komponen penting yang ada dalam rencana pembelajaran meliputi: identitas, kompetensi inti (KI), kompetensi dasar (KD), indikator, tujuan pembelajaran, materi pokok, metode Think Pair Share, langkah-langkah pembelajaran, sumber pembelajaran, dan penilaian, ada siklus I, setelah melalui proses perencanaan pembelajaran hingga terlaksananya pembelajaran di kelas menggunakan metode Think Pair Share telah direfleksi untuk peningkatan keterampilan partisipsi siswa. Jika tujuan dari keterampilan partisipasi siswa belum terlaksana dengan baik, maka perlu perencanaan yang lebih baik pada siklus II. Jadi, setelah dilaksanakan melalui metode Think Pair Share dan diamati oleh peneliti pada siklus I, maka peneliti akan menyiapkan perencanaan pembelajaran pada siklus II sehingga indikator 
keterampilan partisipasi siswa dapat tercapai. Sebelum melaksanakan tindakan, peneliti akan memberi motivasi dan semangat peserta didik yang sesuai dengan materi yang sedang diajarkan agar mudah dipahami siswa. Peneliti juga mempelajari apa kelebihan dan kelemahan yang terjadi di kelas sehingga pada saat tindakan di siklus II guru bisa merencanakan untuk membimbing siswa dengan metode Think Pair Share pada saat mengajar dengan baik, karena dalam metode Think Pair Share memiliki kelemahan sehingga perlu direfleksi disiklus II. Berdasarkan hasil keterampilan partisipasi siswa meningkat tidak terlepas dari perencanaan yang matang. Pada perencanaan ini sudah terlaksana $100 \%$ dari mempersiapkan silabus, menyiapkan RPP, menyiapkan diri, menyiapkan lembar aktivitas guru dan lembar aktivitas peserta didik serta mempersiapkan lembar penilaian keterampilan parrtisipasi siswa.

Berdasarkan hasil pelaksanaan pada siklus I, pembelajaran masih tergolong cukup aktif karena pada saat guru memberikan pertanyaan untuk membangun menggali pengetahuan siswa. siswa masih takut untuk mengemukakan pendapat. Pada saat proses pembelajaran berlangsung masih ada siswa yang tidak berani dan gugup kemudian takut untuk tampil di depan kelas. Pendidik pun berperan penting dalam suksesnya pembelajaran. Ini terjadi ketika guru kurang membiasakan siswa untuk berbicara di depan kelas, kemudian guru belum sepenuhnya membimbing siswa jika ada kesalahan yang terdapat dalam proses pembelajaran. Jadi pada siklus I kemampuan masih tergolong rendah sehingga dilaksanakan siklus II. Pada siklus II ini sudah terlaksana dengan baik, karena siswa sudah bisa melaksanakan pembelajaran sesuai dengan skenario yang terdapat dalam RPP. Pada saat proses pembelajaran sudah banyak siswa yang sesuai indikator keterampilan partisipasi siswa seperti siswa sudah mau untuk mengeluarkan suara dan tunjuk tangan, siswa sudah berani untuk maju kedepan kelas, siswa sudah memperhatikan guru, dan siswa sudah mulai percaya diri saat pembelajaran berlangsung. Berdasarkan hasil pelaksanaan pada siklus I dan siklus II, dapat disimpulkan bahwa keterampilan partisipasi sisswa melalui metode Think Pair Share dapat meningkatkan keterampilan partisipasi siswa kelas IV Sekolah Dasar Negeri 023 Muara Mahat Baru .

Peningkatan keterampilan partisipasi siswa pada siklus I yang berjumlah 27 , peserta didik yang mencapai kategori yang telah ditentukan peneliti yaitu kategori cukup dengan nilai minimal 70 sebanyak 10 orang $(48,14 \%)$, dan siswa yang tidak mencapai kategori yang telah ditentukan peneliti yaitu kategori cukup dengan nilai minimal 70 sebanyak 18 orang $(66,67 \%)$. Dengan menggunakan metode partisipasi, dapat dilihat bahwa nilai rata-rata keterampilan partisipasi siswa kelas IV Sekolah Dasar Negeri 023 Muara Mahat Baru pada tindakan siklus I mengalami peningkatan apabila dibandingkan dengan nilai rata-rata pada kondisi awal. Sedangkan Peningkatan keterampilan partisipsi siswa pada siklus II yang berjumlah 27 orang, siswa yang mencapai kategori yang telah ditentukan peneliti yaitu kategori cukup dengan nilai minimal 70 sebanyak 10 orang $(70,37 \%)$, dan peserta didik yang tidak mencapai kategori yang telah ditentukan peneliti yaitu kategori cukup dengan nilai minimal 70 sebanyak 8 orang (29,62\%). Dengan menggunakan metode Think Pair Sahre, dapat dilihat bahwa nilai rata-rata keterampilan partisipasi siswa kelas IV Sekolah Dasar Negeri 023 Muara Mahat Baru pada tindakan siklus II mengalami peningkatan apabila dibandingkan dengan nilai rata-rata pada siklus II. Peningkatan keterampilan partisipaisi pada siklus II sebesar $48,14 \%$ siklus I $48,14 \%$ meningkat menjadi $70,37 \%$. Hasil perolehan keterampilan partisipasi siswa pada siklus II mengalami peningkatan jika dibandingkan dengan siklus I. Hasil keterampilan partisipasi siswa pada Siklus II secara keseluruhan sebesar $70,37 \%$ dan $29,62 \%$ siswa yang tidak tuntas dari tindakan awal, siklus I, dan siklus II. Hal ini disebabkan karena siswa yang tidak tuntas tersebut dikarenakan mengalami kesulitan belajar.

\section{A. Hubungan Antara Penelitian Terdahulu dangan Peneliti}

Berdasarkan hasil penelitian dapat ditemukan bahwa keterampilan partisipasi siswa dapat mengalami peningkatan hal ini sama terjadi pada penelitian yang dilakukan oleh Hernawati tahun 2007 namun hal ini sama yang ditemukan oleh peneliti sama-sama mengalami peningkatan, namun pada peneliti ditentukan selain kemampuan keterampilan partisipasi meningkat dengan menggunakan proses pembelajaran yang lebih aktif, kreatif dan suasana pembelajaran partisipasinya aktif didalam proses pembelajaran.

Penelitian yang dilakukan oleh Isma Nurhidayati tahun 2009 dan penelitian Rifa Imami penelitian ini yaitu dengan menggunakan metode Think pair Share namun penelitian ini hanya untuk meningkatkan prestasi dalam belajar dan kemampuan siswa sedangkan yang peneliti yang laksanakan hanya mengalami persamaan antara metode yang digunakan yaitu samasama menggunakan metode Think Pair share.

Penelitin terdahulu dengan penelitian yang dilakukan oleh peneliti mengalami persamaan yaitu dengan menggunakan metode Think Pair Share dan juga sama-sama 
mengalami peningkatan, dan penelitian antara penelitian tedahulu dengan penelitian yang dilakukan oleh peneliti sekarang, namun peneliti ini dilakukan di kelas IV Sekolah Dasar Negeri 023 Muara Mahat Baru.

\section{SIMPULAN}

Berdasarkan hasil penelitian dan pembahasan, dapat disimpulkan bahwa keterampilan partisipasi siswa kelas IV Sekolah Dasar Negeri 023 Muara Mahat Baru meningkat dengan menggunakan metode Think Pair Share. Peningkatan keterampilan partisipasi siswa kelas IV Sekolah Dasar Negeri 023 Muara Mahat Baru ditunjukkan dengan adanya peningkatan proses pembelajaran. Peningkatan proses pembelajaran ditunjukkan dengan siswa lebih aktif dalam mengikuti proses pembelajaran menggunakan metode Think Pair Share.

Perencanaan pembelajaran dengan menggunakan metode Think Pair Share, pembelajaran PKn pada materi pentingnya kerja sama dengan menggunakan metode Think Pair Share Perencanaan pembelajaran telah terlaksana dari siklus I tergolong kategori kurang, namun pembelajarannya sesuai dengan materi yang diajarkan, sedangkan siklus II sudah tergolong dengan kategori baik, dan telah sudah terlaksana dengan baik.

Pelaksanaan pembelajaran PKn dengan menggunakan metode Think Pair Share di Siklus I belum terkalaksana dengan baik dan masih banyak kekurangannya, sedangkan pada Siklus II sudah mulai terlaksana dengan baik supaya siswa labih mendapatkan nilai yang lebih baik maka siswa akan diberikan perbaikan agar mencapai nilai ketuntasan. Sehingga pada Siklus II dapat dikatakan meningkat dengan materi pentingnya kerja sama Sekolah Dasar Negeri 023 Muara Mahat Baru.

Peningkatan hasil pembelajaran keterampilan partisipasi siswa kelas IV Sekolah Dasar Negeri 023 Muara Mahat Baru adalah sebagai berikut. Nilai rata-rata hasil partisipasi pada pratindakan mencapai $37 \%$, pada siklus I nilai rata-rata masih rendah. Pada Siklus I pertemuan II mencapai 48,14\%, pada siklus I pertemuan II mengalami kenaikain. Pada Siklus II pertemuan 1 mencapai 62,96 \% mengalami kenaikan. Pada Siklus II pertemuan II mencapai 70,37 \% dan masih bertahan dengan nilai yang bagus. Hasil tersebut menunjukkan bahwa pembelajaran keterampilan partisipaisi siswa menggunakan metode Think Pair Share telah memenuhi indikator partisipasi dalam penelitian ini. Sehingga penelitian ini dapat dikatakan berhasil, maka siklus dapat dihentikan.

\section{DAFTAR PUSTAKA}

Arikunto, S., dkk. (2014). Penelitian Tindakan Kelas. Jakarta: Bumi Aksara.

Aunurrahman. (2012). Belajar dan Pembelajaran. Bandung: Alfabeta.

Fadholi, A (2009). Model Pembelajaran Kooperatif Tipe. Artikel (tidak diterbitkan). http://gedeupadana.blogspot.com/2010/11/model-pembelajaran-kooperatiftipe.html (diakses 6 maret 2019).

Hamalik. (2013). Proses Belajar Mengajar. Jakarta: Bumi Aksara.

Hopkins, david.(2011). Panduan Guru Penelitian Tindakan Kelas. Yogyakarta: Pustaka Belajar

Huda, M (2011). Cooperative Learning. Yogyakarta: Pustaka Pelajar

Ittihat. (2007), Penertian Pendidikan Kewarganegaraan . Jakarta: Ghalia Indonesia

Jalal, Fasli dan Dedi Supriadi, (2001), Reformasi Pendidikandalam Konteks Otonomi Daerah, Yogyakarta: Adicita Karya Nusa

Komalasari, K. (2010). Pembelajaran kontekstual (konsep dan aplikasi). Bandung: Refika Aditama

Kurniasih, Imas Dan Berlin Sani. (2015). Ragam Pengembangan Model Pembelajaran Untuk Peningkatan Profesionalitas Guru.Yogyakarta: Kata Pena

Poerbakawatja, Suegarda.(1981). Ensiklopedi Pendidikan. Jakarta: Gunung Agung

Purwanto, (2014). Evaluasi Hasil Belajar. Yogyakarta: Pustaka Pelajar

Rohman. (2009). Memahami Pendidikan dan ilmu Pendidikan.Yogyakarta: Laksbang Mediatama.

Ross, Angell. (1967). Partisipasi.http://Faktor-Faktor Partisipasi. Fakultas IImu Sosial dan IImu Praktik.jurnal ilmu dan administrasi dan sosial. (diakses 20 april)

Rumiati. (2007). Pengembangan Pendidikan Kewarganegaraan SD. Depdiknas. Jakarta

Rusman. (2012). Model-model Pembelajaran Mengembangkan Profesionalisme Guru. Jakarta: Rajawali Pers.

Soemarjadi, Musni Romanto, Wikdati Zahri. (1991). Pendidikan Keterampilan. Jakarta: Depdikbud 
Solihatin, (2012). Strategi Pembelajaran PPKN. Jakarta: Bumi Aksara

Sugiyono, (2010). Metode Penelitian Kuantitatif, Kualitatif, dan R \& D, Bandung: Alfabeta

Suharsimi Arikunto, dkk. (2010). Prosedur Penelitian Suatu Pendekatan Praktik, Jakarta: Rineka Cipta

Sukidin. (2002). Metode Penelitian Kualitatif Perspektif Mikro. Surabaya. Insan Cendikia Suryosubroto. (2002). Proses Belajar Mengajar Di Sekolah , Jakarta; Rineka Cipta

Trianto. (2007). Model-model Pembelajaran Inovatif Berorientasi Kontruktivistik. Surabaya. Prestasi Pustaka Publisher.

Trianto. (2011). Model-model Pembelajaran Inovatif berorientasi Konstruktivistik. Jakarta: Prestasi Pustaka.

Undang - undang No. 20 Tahun 2003. Tentang Sistem Pendidikan Nasional. Jakarta: Depdiknas Wahab, Azis.(2007). Pendidikan Pancasila dan Kewarganegaraan. Jakarta. Universitas Terbuka

Zainal Aqib. (2013). Model-Model Media dan Strategi Pembelajaran Kontekstual (Inovatif). Yama Widya: Bandung 